\title{
Perancangan dan Implementasi Peraga Bahasa Isyarat Menggunakan Tangan Robot untuk Penderita Tuna Rungu
}

\author{
Muhammad Angga $\mathrm{P}^{l}$, Pitoyo Yuliatmojo ${ }^{2}$, Taryudi ${ }^{3}$ \\ ${ }^{1}$ Mahasiswa Prodi Pendidikan Teknik Elektronika, Fakultas Teknik - UNJ \\ ${ }^{2}$ Dosen Prodi Pendidikan Teknik Elektronika, Fakultas Teknik - UNJ \\ ${ }^{3}$ Dosen Prodi Pendidikan Teknik Elektronika, Fakultas Teknik - UNJ
}

\begin{abstract}
Abstrak Tuna Rungu adalah orang yang sedang mengalami gangguan pada organ pendengarannya, sehingga tidak bisa memahami orang normal dalam mendengar maupun berkomunikasi dengan baik di lingungan sekitarnya, bahasa isyarat merupakan salahsatu dari cara berkomunikasi dengan penderita Tuna Rungu. Metode penelitian yang dipakai penulis adalah dengan metode research and development. Penelitian dengan berjudul "Perancangan dan implementasi peraga bahasa isyarat menggunakan tangan robot untuk penderita Tuna Rungu" bertujuan membuat sistem yang memiliki prinsip kerja sebagai alat peraga robot bahasa isyarat satu tangan, yang terdapat pada kamus bahasa isyarat indonesia, yaitu dengan cara menampilkan gestur atau isyarat visual alphabet dan angka lalu digerakan dengan motor servo melalui aplikasi android dan mikropon pengenalan suara. Tangan robot peraga bahasa isyarat menggunakan 11 Motor servo sebagai penggerak atau aktuator pada setiap jari-jari, dan pergelangan robot untuk inputnya yang pertama menggunakan menggunakan Voice Recognition EasyVR, EasyVR adalah salahsatu modul voice recognition modul ini berfungsi sebagai penerima perintah suara, ketika microphone menerima suara yang masuk yaitu berupa salahsatu alphabet maka proses di dalam modul EasyVR akan menerima perintah lalu data masukan tersebut akan diproses dalam arduino, keluaran arduino akan mengaktifkan motor servo sehingga membentuk gestur yang terdapat pada bahasa isyarat serta akan menampilkan pada layar LCD 16x2 Huruf dan Angka yang diucapkan melalui microphone EasyVR, dan input yang kedua menggunakan aplikasi pada android yang dibuat sendiri menggunakan software MIT app Inventor. Hasil Penelitian Tangan Robot Bahasa Isyarat dapat direalisasikan dengan penggabungan sub-sistem yang berfungsi dengan baik, diantaranya : Arduino Mega 2560, Modul Voice Recognition EasyVr, Sistem Display berbasis LCD 16x2 dan I2C, Modul Bluetooth, 32 Channel servo controller, dan Baterai Li-Po. Sistem Tangan Robot Bahasa Isyarat menggunakan bahan plastik (Pla) yang dicetak menggunakan 3D Printer dan Tangan Robot Bahasa Isyarat dapat digerakan dengan aplikasi android yang dapat di unduh, dan sensor suara, lalu dapat bergerak otomatis menampilkan gestur atau isyarat visual yang sudah terprogram derajat pergerakannya.
\end{abstract}


Kata Kunci: Tangan Robot, Bahasa Isyarat, Voice Recognition, Mikrokontroller Arduino, Robot abjad jari.

\section{Pendahuluan}

Bahasa isyarat merupakan cara komunikasi visual yang digunakan oleh orang-orang yang memiliki keterbatasan dalam melakukan komunikasi lisan secara normal, contohnya seperti penderita Tuna Rungu yang menggunakan Bahasa isyarat sebagai cara untuk berkomunkasi.Permasalahan tersebut melatar belakangi dibuatnya "Perancangan dan implementasi peraga bahasa isyarat menggunakan tangan robot untuk penderita Tuna Rungu" yang berfungsi sebagai alat pengeja abjad jari dengan arduno yang terhubung dengan 11 buah Motor Servo sebagai penggerak utama jari robot dan Penulis menggunakan desain dasar dari tangan robot inmoov dan diubah bentuknya agar desain tangan robot bisa sesuai dengan fungsinya, Pembuatan tangan robot tersebut menggunakan bahan plastik Pla yang dicetak dengan 3D printing, dan untuk menerima Huruf dan Angka diperlukan sensor suara yaitu modul Easy VR.

\section{Metode}

Tempat perancangan alat dilakukan di Laboratorium Otomasi Industri Fakultas Teknik Universitas Negeri Jakarta dan di Bengkel Mekanik Teknik Elektro Universitas Negeri Jakarta.

\section{Hasil}

\subsection{Hasil Pengembangan Produk}

Pada bab ini membahas mengenai hasil pembuatan bagian-bagian alat yang telah dirancang dan membahas mengenai Sistem peraga bahasa isyarat dengan menggunakan tangan robot untuk penderita tuna rungu Dengan menggunakan 11 Servo dan masing-masingnya mempunyai fungsi tersendiri. Gambar 3.1 adalah gambar tangan robot yang berhasil dibuat

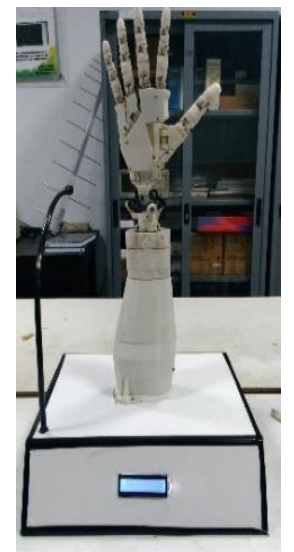

Gambar 3.1 Betuk Fisik Alat 


\subsubsection{Pengujian Keseluruhan system}

Pengujian rangkaian sistem secara keseluruhan dilakukan dengan cara menghubungkan semua hardware, yaitu rangkaian Motor Servo, modul EasyVR, modul Blueetooth dengan Android, Motor Servo, Arduino Mega 2560, Modul LCD 16x2. Tujuan pengujian rangkaian sistem secara keseluruhan untuk mengetahui apakah alat yang dirancang dapat bekerja dengan baik.

Tabel 3.1 Pengujian Huruf dan Angka

\begin{tabular}{|c|c|c|c|}
\hline kin & Pragejlat & $\begin{array}{l}\text { Wuki } \\
\text { prows } \\
\text { drriky }\end{array}$ & 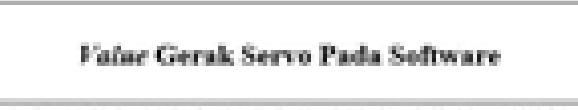 \\
\hline 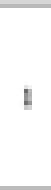 & A & 4 & 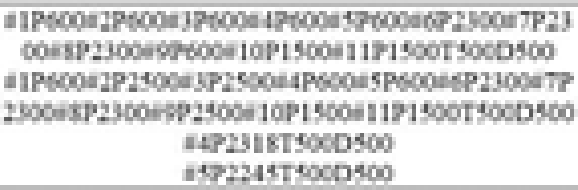 \\
\hline 2 & H & y & 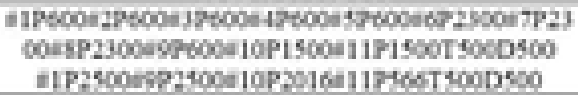 \\
\hline y & C & y & 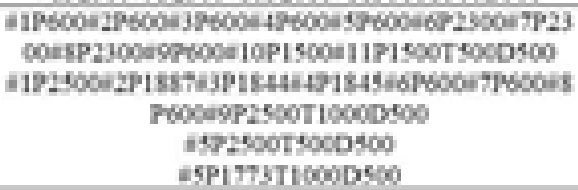 \\
\hline
\end{tabular}

Tabel 3.2 Validasi Gerak Robot Per Huruf

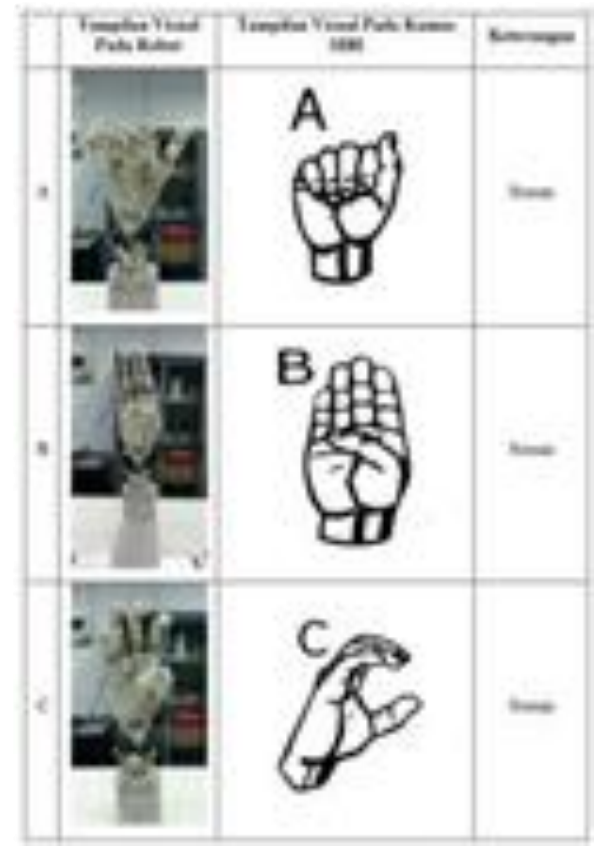




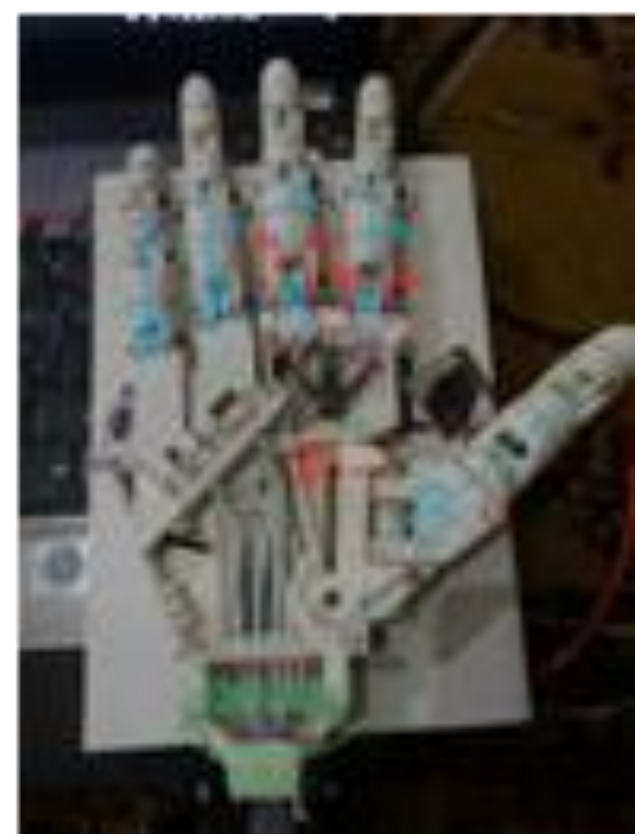

Gambar 3.2 Gerakan Servo pada Tangan Robot

\subsection{Pembahasan Hasil Penelitian}

tahap akhir bertujuan untuk mengetahui apakah sistem Tangan Robot Bahasa Isyarat dapat membentuk isyarat sesuai buku kamus bahasa isyarat indonesia, Untuk mengetahui keberhasilan pergerakan per-Huruf dan Angka.

$$
\begin{aligned}
\text { \% keberhasilan } & =\frac{\text { Keberhastan per kata }}{\text { whi coba }} \times 100 \% \\
& =\frac{3}{3} \times 100 \% \\
& =100 \%=\text { Sesuai }
\end{aligned}
$$

Menghitung kelayakan seluruh sub sistem Tangan robot bahasa isyarat adalah perhitungan dari persentasi keberhasial dari seluruh Huruf dan Angka dan sub-sistem.

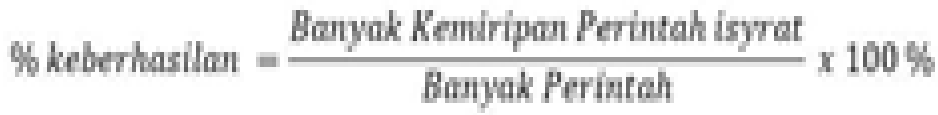

$$
\begin{aligned}
& \frac{28}{35} x 100 \%=80 \%
\end{aligned}
$$

\section{Kesimpulan}

Perancangan dan implementasi peraga bahasa isyarat menggunakan tangan robot untuk penderita Tuna Rungu berjalan dengan baik dimana Tangan Robot dapat menerjemahkan 
alphabet dan numerik dari aplikasi android yang berfungsi memudahkan input pergerakan robot jika dalam keadaan ramai suara yang saling terkoneksi dengan Bluetooth.

\section{DATAR PUSTAKA}

1. Moores, Donald F. (2001). Educating The Deaf, Psychology, Principles and Practices, Houghton Mifflin Company, Boston, New York.

2. Boothroyd, Arthur (1982), Hearing Impairments in Young Children, Prentice Hall, Inc.

3. Englewood Cliffs, New York. Fu, King Sun, Gonzales, R. C. , Lee, C. S. G. (1987). Robotics : control, sensing, vision and intelligence. McGraw-Hill. Singapore.

4. Langevin, G. (2014) InMoov-Open source 3D printed life size robot. http://inmoov.fr/ Diakses 13 Januari 2018.

5. Djuandi, Feri. (2011). Pengenalan Arduino. https://www.tobuku.com, Diakses 8 Januari. 2018.

6. Arduino. (2015). https://www.mouser.co.id/ProductDetail/Arduino/A000066. Di Akses 18 Febuari 2018.

7. Tamam, B. (2017). Rancang Bangan Robot Line Follower Pemadam Api Memanfaatkan Flame Sensor Dan Bluetooth Berbasis Arduino [skripsi]. Jakarta: Fakultas Teknik, Universitas Negeri Jakarta

8. Ichsan, M. (2017). Prototype Pengendali Lampu Dan Pintu Otomatis Dengan Voice Recognation Pada Rumah Pintar, 1-72 [skripsi]. Jakarta: Fakultas Teknik, Universitas Negeri Jakarta.

9. Shaileen Crawford Pokress, José Juan Dominguez Veiga. (2013). "MIT App Inventor: Enabling Personal Mobile Computing.” PRoMoTo 2013 proceedings, October 2013. http://arxiv.org/abs/1310.2830.

10. Prof. Deddy Mulyana, MA, Ph.D, (2012) "Ilmu Komunikasi” , Bandung : Suatu Pengantar, Rosda, : 76.

11. Hallahan, \& Kauffman. (2006). Exceptional learners: Introduction to special education 10 th ed. Boston.

12. Holtz, J. (1994). "Pulsewidth modulation for electronic power conversion."

13. IEEE Proceedings, 82(8) : 1194-1 Imario, A., Sudiharto, D. W., \& Ariyanto, E. (2017). Uji Validasi Suara Berbasis Pengenalan Suara (Voice Recognition) Menggunakan EasyVR 3.0. Prosiding SNATIF, 4, 801-806. 